\title{
NURSING STUDENTS' PERCEPTION OF THE LEARNING PROCESS IN A HOSPITAL SETTING
}

\author{
Elcilene Andreíne Terra Durgante ALVES ${ }^{\mathrm{a}}$, Ana Luísa Petersen COGO ${ }^{\mathrm{b}}$
}

\section{ABSTRACT}

The aim of this study was to identify how nursing students perceive and experience the learning process during curricular practice in a hospital setting. A qualitative, retrospective, documentary study was developed in an undergraduate nursing course. Data were comprised of 162 posts made by 34 students in the online discussion forum of the Learning Management System Moodle, during the first half of 2011. The following themes emerged from the thematic content analysis: "nursing students' understanding about the professional practice," and "the teaching and learning process in the perspective of nursing students." The study demonstrated that the forum was a place for reporting experiences such as the description of the physical area, performing procedures, perception of nursing care activities, conflicts with peers, coping with death and learning evaluation. The online discussion forum needs to be used by professors as a space of interaction so as to contribute to professional training.

Descriptors: Nursing. Education, Nursing. Students, Nursing. Educational technology.

\section{RESUMO}

O estudo teve como objetivo identificar como estudantes de enfermagem perceberam e vivenciaram o processo de aprendizagem durante práticas curriculares realizadas em ambiente hospitalar. Tratou-se de pesquisa documental retrospectiva qualitativa, desenvolvida em Curso de Graduação em Enfermagem. Compuseram os dados 162 registros realizados por 34 estudantes em fórum no ambiente virtual Moodle, no primeiro semestre de 2011. Da análise de conteúdo temática emergiram os temas: 'a compreensão dos estudantes de enfermagem sobre a prática profissional' e 'o processo de ensino e de aprendizagem sob a ótica dos estudantes de enfermagem'. O estudo demonstrou que o fórum foi um espaço de relato das vivências, como a descrição da área física, a realização de procedimentos, a percepção das atividades assistenciais do enfermeiro, os conflitos com colegas, o enfrentamento da morte e a avaliação da aprendizagem. Ofórum necessita ser utilizado pelos professores como um espaço de interação, contribuindo para a formação profissional.

Descritores: Enfermagem. Educação em enfermagem. Estudantes de enfermagem. Tecnologia educacional. Título: Percepção de estudantes de enfermagem sobre o processo de aprendizagem em ambiente hospitalar.

\section{RESUMEN}

El estudio tuvo como objetivo identificar cómo los estudiantes de enfermería perciben y experimentan el proceso de aprendizaje durante las prácticas en el hospital. Se trata de una investigación documental retrospectivo-cualitativa desarrollada en Curso de Licenciatura en Enfermería. Compuesto por 162 registros de datos realizados por 34 estudiantes en el foro Moodle entorno virtual en el primer semestre de 2011. Los temas de análisis de contenido temático que se sugirieron fueron 'comprensión de los estudiantes de enfermería sobre la práctica profesional' y 'el proceso de enseñanza-aprendizaje desde la perspectiva de los estudiantes de enfermería'. El estudio demostró que el foro de discusión fue un espacio de presentación de informes de experiencias como una descripción del área física, la realización de los procedimientos, la percepción de las actividades de atención de enfermería, los conflictos con los compañeros, hacer frente a la muerte y la evaluación de los aprendizajes. El foro necesita ser utilizado por los profesores como un espacio de interacción contribuyendo con la formación.

Descriptores: Enfermería. Educación en Enfermería. Estudiantes de Enfermería. Tecnología educacional. Título: La percepción de los estudiantes de enfermería del proceso de aprendizaje en medio hospitalario.

a R.N., Master in Nursing. Nurse at the Emergency Hospital of Porto Alegre. Porto Alegre, Rio Grande do Sul, Brazil.

b R.N., Ph.D. in Nursing, Professor at the Medical-Surgical Nursing Department and the Nursing Graduate Program of the Federal University of Rio Grande do Sul (UFRGS). Researcher of the Study and Research Group in Nursing, Education and Technologies (GEPEETec). Porto Alegre, Rio Grande do Sul, Brazil. 


\section{INTRODUCTION}

Nurses perform their functions in the areas of care, education, research and management, and caring for human beings is at the core of all of these activities. The development of the skills necessary to work in nursing should begin during the undergraduate training, being improved during years of professional practice, training nurses to play an active and critical role in health care, contributing effectively in decision-making, social and institutional issues, and directly reflecting on the quality of the care service provided to society ${ }^{(1-3)}$. The integration of theoretical and practical activities supported by different teaching methods should promote the integration of nursing students into the context of health care practice ${ }^{(4)}$.

During the professional training, nursing students experience their first curricular practices both in primary care and in the hospital, coming into contactwith the reality of the Brazilian health care. During these practices, nursing students should use the technical-scientific knowledge previously gained theoretically in the course, perform technical activities inherent to the profession, and establish interpersonal relationshipswith colleagues, professors, patients and their families, and other health care professionals, interacting and working in a critical and reflective manner. Provided with this diversity of skills and attitudes to be developed in the hospital curricular practice, it is understandable that nursing students experience a high degree of stress $^{(5)}$. According to some studies, this is caused by the lack of knowledge of the vocabulary being used by professionals, lack of maturity of students, or deficient training in basic subjects ${ }^{(6-7)}$. Therefore, it is necessary that professors use strategies to understand and address the experiences of the students training in hospitals, providing the opportunity to dialogue, reflect, review, and modify their way of experiencing the situations they face, minimizing the damage caused by stress, meeting the students' needs, and contributing to their development ${ }^{(8-9)}$.

Among the pedagogical resources available for this purpose are digital educational technologies (DETs), including chats, discussion lists and discussion forums ${ }^{(8-11)}$. Nevertheless, the use of DETs is not the solution to the problems of the field, butamethodological optionwith positive characteristics that allow students to develop dialogue, interaction and autonomy, in addition to being flexible to different schedules and paces of study, and contributing to the qualification of educational processes ${ }^{(9-10)}$. In the context of undergraduate learning and nursing practice, it is understood that dialogue is directly related to the ability to reflect on knowledge and the care process, i.e., the moment of dialogue between the participants, encouraging students to act responsibly, evaluating and modifying their practice, thus enabling them to pursue their profession with greater qualification and respect for patients.

In this context, the online discussion forum is a space in which participants can discuss previously defined themes. This resource allows nursing students to share their opinions andfeelings, providing exchange between participants and thus restructuring their knowledge $\mathrm{e}^{(8-9)}$. Due to its characteristics, it is a tool that enables nursing students to reflect, interact and discuss issues arising from the teaching and learning process.

Interaction is understood as the process developed in exchanges between participants, enabling the review of concepts, the discussion of viewpoints and the construction of new, collective knowledge $\mathrm{e}^{(12)}$. Within an online forum, the interaction between the participants, when constant and multidirectional, helps to stimulate critical thinking and more profound exploration of the proposed themes $^{(8)}$.

It is important to highlight that using this resource will only be valid if the students and professors involved in the process take an active stance, demonstrate interest in the topics discussed, and take positionson the opinions presented, thereby interacting, talking, and redefining themselves and the world ${ }^{(19)}$. Knowledge on the use of the virtual forum as a mediation tool for dialogue during the process of teaching and learning of curricular practices in nursing will contribute to build more effective and individualized interventions in undergraduate teaching. Thus, this study questioned: What experiences and perceptions have nursing students reported in online forums, when performing curricular practices in the hospital environment?

Based on the above, the aim of this study was to identify how nursing students perceive and 
experience the learning process during curricular practices performed in a hospital setting.

\section{METHODOLOGY}

This was a retrospective, documentary study with a qualitative approach ${ }^{(14)}$, guided by the ethical-critical-political theory of education of Paulo Freire ${ }^{(19)}$, and developed in an undergraduate nursing course at a public university. The nursing students perform curricular practice in hospitals during the 4th year of the undergraduate course, with a workload of 225 hours, corresponding to 15 credit weeks, divided into theoretical activities, practice in teaching laboratory, and four weeks of curriculum practice developed at the university teaching hospital.

The data used in this study were derived from 162 posts in the discussion forum of the learning management system Moodle Institutional, by 34 nursing students in the fourth year of the course, in the discipline that developed semiotics and semiology content during the first semester of 2011. Although 36 students were enrolled, two did not make any post in the forum. Theoretical and practical activities were developed in this course, many of which occurred in the hospital. The students developed weekly reports, posting them in the Moodle forum during extra-curricular hours.

The Moodle forum postings were downloaded by the researchers, after obtaining approval from the Institutional Ethics Committee. To ensure the anonymity of the participants, the records were coded with the letter "E", followed by a number ranging from 1 to 36 , according tothe download order of the posts from Moodle. The NVivo $9{ }^{\circledR}$ software was used to manage the information, which were subjected to thematic content analysis $^{(12)}$. This analysis technique involved three phases: pre-analysis, exploration of the material and treatment of the results through inference and interpretation $^{(15)}$.

The study was approved by the Institutional Research Committee (09/2012) and by the Research Ethics Committee of the university under the CAAE number 02007812.6.0000.5347, as informed in the results of the master's degree thesis submitted to the Nursing Graduate Program of the Federal University of Rio Grande do
$\mathrm{Sul}^{(16)}$. The researchers ensured the confidentiality of the identities of the students by signing a Data Use Term. These data will be archived for a period of five years, and destroyed in the end of this period.

\section{RESULTS AND DISCUSSION}

Of the $34(100 \%)$ nursing students who published posts in the Moodle forum, 28 (82.35\%) completely fulfilled the activity with four reports, that is, they submitted one report for each week of curriculum practice, and $24(70.58 \%)$ students made their entries within the requested deadline, which was within one week after the activity had occurred. There was no pre-established format for the posts, the students were simply requestedto describe their impressions and feelings, and to share their experiences with colleagues and professors.

Two themes emerged from the data analysis: 1) nursing students' understanding about the professional practice; and 2) the teaching and learning process in the perspective of nursing students. The findings on both themes are described in detail as follows.

\section{1) Nursing students' understanding about the professional practice}

For some students, the first week of curricular practice was their first contact with the hospital environment, when they witnessed and experienced work as nurses, and became acquainted with the work environment and routine.

The initial postings of the students portrays how they perceived this first contact:

This unit is characterized as a clinical area [...] it has 45 beds and 9 wards for quick procedures

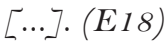

I was thrilled to get to know the floor and how it functions, because I realized that in the next few days, I would be a part of that "scheme." (E24)

In the first week of my internship, in addition to much anticipation, I hada lot of questions: what would my floor be like? What would my internship professor be like? As we had had very little contact. How would it be to work with a team of colleagues who were all experienced technicians? (E6) 
Whereas some students limited their posts to physical and structural descriptions of the units in which their curriculum practices were taking place, others expressed the feelings they experienced in this first contact. The initiation of the student into the hospital environment involves complex issues such as hard technologies, the health and disease process, health care policy, and especially interaction with other participants in this process, which are associated with insecurity, uncertainty and anxiety of the students facing an unknown experience and factors that often generate stress ${ }^{(5)}$.

The conflicts arising in human relationships accompany professionals throughout their careers, and also appeared in the forum posts, in which differences were reported between students, between students and patients, or professors, and even health care professionals. These situations of conflict were evident in the discourse of the student below:

On Wednesday, bringing a chair to take my patient to the bathroom, I made a very negative comment [...]. Upon entering the room to get the patient, I heard the following comment: "I thinkEO4 is in the wrong profession." I was wrongly taking out all of my frustrations and problems on that man, but those who believe that they will never make the same mistake I made are mistaken. Those who believe they will be able to provide human$i$ zed care in all situations, will be able to go into a unit smiling every day, and leave even happier, are mistaken.I am a 21-year-old who has a lot to learn, whetherby watching others doing it right, or reflecting upon my mistakes, and I think my ability to practice this profession is unquestionable. I will be a great professional, and neither I nor anyone should question this. This is the profession I chose for myself, and making my mistakes, I'm willing to go to the end. (E4)

In this passage, the conflicts experienced by the students during their hospital curricular practice can be observed, which require the professor's attention. First there was the internal conflict of the student, provoked by contact with the patient. While acknowledging the premise of nursing care, in which the care needs of the patient must be met by the caregiver, in order to encourageindividuality and self-reliance of the patient ${ }^{(17-18)}$, the student questioned the application of these principles in practice and demonstrated ethically inappropriate questions.
At a second moment, the conflict with colleagues emerged, represented by criticism, that although well-founded consideringthat they were in a hospital ward with professionals, patients and family members, generated a feeling of indignation in the student. In this passage, the student expressed his ambivalence with the everyday, in which the future healthcare professional is torn between providing care focused on preservation of the independence of the patient, or providing care that could speed up and facilitate his work, andhe used irony as a way to express his insecurity. In addition to vehemently expressing his determination to become a nurse.

It is important to realize that when students express their point of view, they reveal their values and beliefs, signaling the professor's responsibility to listen and promote a critical and reflective process with them. The practice of care occurs between individuals, involving the feelings and experiences of everyone involvedand, thus, these should be globally considered ${ }^{(1)}$. When entering the academic life, nursing students are driven by the idea that nursing is a profession focused on the care of others, and that the only function of nursing is the caring nature of the process $^{(19)}$.

Although in the course of the curricular practice the students coexisted with nurses in the inpatient units, experiencing their routines and learning aboutnursing on a profound level, their observations maintained the same focus, i.e., they observed and described only the role of these professionals as caregivers:

I was a little nervous to see such a dramatic change in her appearance, but soon the professor provided the care needed in such situations. Then I could see the importance of the nurse's knowledge, and the ability of the nurse to intervene on behalf of the patient. (E14)

As a caregiver, I realized the importance of proper communication for each patient, and that the technique is only part of the care process, because we always meet people weakened by their illness, causing more than just physical discomfort, an uncertainty about the future. (E7)

The statement of E14 was focused on the nurse's role as a caregiver, but it should be considered that in this stage of the undergraduate 
program, students value the nurses' knowledge of patient care. This limited view of the nursing work will be reviewed throughout the training period and, in the final years of the undergraduate course, the students will be able to demonstrate a real understanding of all of the responsibilities that being a nurse entails ${ }^{(18)}$. The perception of $\mathrm{E} 7$ on the importance of communication skills in nursing care reinforced the exclusive focus on the implementation of procedures, which has been reported by some students. This reinforces the importance that nursing students perform comprehensive care in the curricular practices of introductory course disciplines.

Another important moment reported by students was the monitoring of patients who were dying. The experience of death and human frailty makes students express feelings of sadness, empathy and helplessness ${ }^{(20)}$. These feelings arose because although death is part of life, during their undergraduate studies and professional practice, the topic was not addressed. Nursing curricula address issues related to life, therapy, cure, and do not prepare students to deal with human finitude.

When the activity was finished, the examined patient died, and it was very hard to be there at the time. It was something that affected my colleagues and me. (E31)

[...] I believe I will never forget that face, looking at me and saying: "I want food." That affected me a lot, because besides seeing someone between life and death, I could contemplate all that suffering that he showed, by the fact of being in that situation, and not able to eat anything. (E 22)

These reports show the vulnerability of the health careprofessional as a human being, also exposed to risks, diseases, suffering and death, so that such feelings induce students to experience ambivalent reactions, with some distancing themselves from patients as a defense, whereas others get closer and mourn ${ }^{(20)}$. Facing these situations helped the students to understand that the practice of nursing involves much more than the study of pathologies, medicines or procedures. In fact, it means understanding and respectinghuman frailties.

There are different feelings experienced within the hospital environment, and little time available to perform daily tasks to establish a moment of dialogue to address these issues in a reflective manner. When ignored, these feelings can lead students to extreme suffering, negatively interfering in the learning process ${ }^{(5)}$. These factors must be known to professors, enabling them to develop an action plan that aims at minimizing the suffering of students, and contributing to their process of maturing. It is believed that the virtual environment forum can be used as a space for students to describe their feelings, expectations and difficulties, complementing in-person dialogue during the curricular practice.

\section{2) The teaching and learning process in the perspective of nursing students}

As previously discussed, the students in the first years of the undergraduate nursing course perceived their profession as essentially related to care, so they believe that curricular practice starts with the realization of technical procedures, as highlighted below:

On 30/O5 we started our first day of the internship [...]
we got to know the unit, some employees and talked to the
professor [...]. On 31/O5 we actually began our intern-
ship. [...] We checked their vital signs, assisted in shower
bathing, put on a bandage on the right lower limb with
o.9\% saline solution (2 ${ }^{\text {nd }}$ right toe). We administered
medications orally, subcutaneously and intravenously.
It was a very productive morning! (E 23)

Performing procedures is important to the students, since the improvement of technical skills is their main concern at the beginning of curricular practice $^{(17)}$. This aspect was observed in the forum postings over the weeks, with a total of 582 references in the field diary. Most of the students' postswere reports of procedures observed or performed, as well as the feelings provoked by these experiences:

I inserted an Abocath 24 into patient L., eleven years old. I changed the dressing on the catheter. I loved performing all of the tasks. (E 21)

Upon checking vital signs, because of nervousness, I was only unable to perform measurement of the blood pressure. This being my first contact with a hospitalized patient as a nursing student, I thought I could have let go more. The pressure to perform the tasks 
correctly in a new environment was great, even with the help of the professor and the monitor, the tension prevailed. (E 13)

In these passages, the anxiety of the students in the face of performing procedures with patients is clear. They reported how the feeling interfered with performing the technique and, in some cases, led the students to stress and suffering, hindering their learning. This study showed that in addition to preparing students to perform the procedures through theory and simulation of the technique in nursing laboratories, it is necessary to stimulate discussion of the feelings they experience in real situations, reflecting and exchanging information with their peers, and building forms of coping with the difficulties ${ }^{(17)}$.

There are several ways to give students time to reflect and exchange, one of them being the use of virtual learning environments such as discussion forums, which allow students to share their feelings and perceptions, and have these read and discussed among the group members. These moments of reflection promote changes, after review and evaluation of the context in which they are inserted ${ }^{(19)}$.

The students in the forum also expressed their feelings and the difficulties they faced, as shown in the following excerpt:

It was very difficult for me! I didn't know which position to take, I was outraged and unable to work around the situation well. (E 12)

In summary, this internship provided me with knowledge from the first to the last day, including the lessons in the laboratory and the evaluation day, and will surely contribute to my professional development and construction; I will take the experiences and tips mentioned by the professor during my entire professional and personal life. (E 21)

We presented our cases and did the evaluations. I really liked the evaluation time with the professor, because we had made the same observations. Ifelt at ease to be very frank with her about my observations and feelings on the internship. Thus, I think we are able to see ourselves as future professionals and grow with the suggestions we received. (E 39)

In the reports above, the students performed a self-assessment and cited feelings of sadness, anger, powerlessness, as well as satisfaction and feelings of having completed the first phase of their professional training. They used the space of the field diary to address the difficulties and discoveries that they encountered when beginning their activities in the hospital unit, and the professors could use this spaceof interaction, establishing a relationship of dialogue.

Concern with the final concept and approval emerged in the statements of the students, however, many reinforced the learning and examples of professionals with whom they worked in this stage of the course. This was a demonstration of maturity and commitment to their qualification as professionals and citizens. In this context, evaluatinginvolves creating opportunities for dialogue between the student and professor, providing both with the opportunity to review their actions and concepts, changing themselves and others. It means to see the student as a person with knowledge, capable of learning and teaching, for only like this professionals capable of perceiving themselves, and thus respecting others, will be trained ${ }^{(21)}$.

\section{CONCLUSION}

This study presented the perceptions of nursing students about the hospital curricular practice that they performed, reinforcing the importance of providing spaces that promote dialogue. The initial reports, posted soon after the students arrived at the hospital, were descriptions of the physical space, foreign to most of them. According to the students, the work of nurses is linked to direct care, with no perception of a greater dimension. Identification with the profession, and criticism between colleagues, demonstrated the importance of broaching ethical issues among students, also reflecting on situations of sadness and bewilderment in the face of human frailty and death.

The process of teaching and learning was evaluated at various times, signaling that the forum provided an opportunity to express their perceptions and their criticisms, and some of the students understand their training as a process that is just beginning, in which not only technical skills are essential, but also the examples to be followed, such asthe attitudes of a professor. It is noteworthy 
that in the statements of the participants, the term "internship" was used as a synonym for curricular practice, demonstrating that the students have not yet incorporated the title used incurrent curriculum guidelines.

Digital technologies for education have contributed significantly to nursing education, and the online forum tool proved to be a supportive resource, although it needs to be used by professors as a space for interaction, not just listening. Thus, it is recommended that other studies be developed with the aim to integrate the use of technology with pedagogical guidance, in order to contribute to the professional training. The limitation of this study relates to the use of data produced by students freely without systematization, which may have caused the omission of experiences and perceptions that would provide a deeper analysis of the topic.

\section{REFERENCES}

1 Kikuchi EM,Mendes MMR. O cuidado no processo de avaliação da aprendizagem: um enfoque fenomenológico. CiêncCuid Saúde. 2012;11(Suppl):23-30.

2 Erdmann AL, Fernandes JV, Melo C, Carvalho BR, Menezes Q, Freitas R, et al. A visibilidade da profissão de enfermeiro: reconhecendo conquistas e lacunas. RevBrasEnferm. 2012;62(4):637-43.

3 Corbellini VL, Santos BRL, Ojeda BS, Gerhart LM, Eldt OR, Stein SC,et al . Nexos e desafios na formação profissional do enfermeiro. Rev Bras Enferm. 2010;63(4):555-60.

4 Crookes K, Crookes PA, Walsh K. Meaningful and engaging teaching techniques for student nurses: a literature review. Nurse Educ Pract. 2013;13(4):23943.

5 Santos EPS, Radünz V. O estresse de acadêmicas de enfermagem e a segurança do paciente. RevEnferm UERJ. 2011;19(4):616-20.

6 AlmeidaAH, Soares CB. Educação em saúde: análise do ensino na graduação em enfermagem. Rev Lat-Am Enfermagem. 2011;19(3):21-9.

7 Carlson E, Pilhammar E, Wann-Hansson C. "Thisis nursing": nursing roles as mediated by precepting nurses during clinical practice.Nurse Educ Today. 2010;30(1):763-7.
8 Skogs J. Subject line preferences and other factors contributing to coherence and interaction in student discussion forums. Comput Educ.2013;60(1):172-83.

9 Bicalho RNM, Oliveira MCSL. O processo dialógico de construção do conhecimento em fóruns de discussão. Interface - Comunic, Saude, Educ. 2012;16(41):469-83.

10 Silva APSS, Pedro ENR. Autonomy in nursing students process of knowledge construction: the educational chat as a teaching tool. Rev Lat-AmEnfermagem. 2010;18(2): 210-6.

11 Portella VCC, CrossettiMGO, Baron DAC, Mendes ENW, CrippaSPS. Fórum em ambiente virtual na relação de confiança entre o profissional e o indivíduo cuidado. Rev Gaúcha Enferm. 2012;33(4):72-8.

12 Primo A. Enfoques e desfoques no estudo da interação mediada por computador [Internet]. 2005. 16 p. [citado 2014 fev 24] Disponível em: http://www. ufrgs.br/limc/PDFs/enfoques_desfoques.pdf

13 Freire P. Pedagogia do oprimido. Rio de Janeiro: Paz e Terra; 2011.

14 Polit DF, Beck CT,Hungler BP. Fundamentos de pesquisa em enfermagem: métodos, avaliação e utilização. Porto Alegre: Artmed; 2004.

15 Bardin L. Análise de conteúdo. Lisboa: Edições70; 2011.

16 Alves EATD. Vivências e percepções de acadêmicos de enfermagem em fórum online [dissertação]. Porto Alegre (RS): Escola de Enfermagem, Universidade Federal do Rio Grande do Sul; 2013.

17 Fonseca AM, Campos ACV, Cotta FMP, Borelli LR, Dutra BS, Santana JCB.Reflexões éticas sobre o cuidado humanizado na percepção dos enfermeiros. Ciênc Saúde. 2010;3(1):2-8.

18 Garanhani ML,Valle RM. O olhar do aluno habitando um currículo integrado de enfermagem: uma análise existencial. Ciênc Cuid Saúde. 2012;11(Suppl):87-94.

19 Borges AG, Vannuchi MTO, Gonzáles AD, Vannuchi RO. Caracterização e expectativas de estudantes ingressantes de um curso de graduação em enfermagem. Rev Espaço Saúde. 2010;12(1):1-6. 
20 Santos JL, Bueno SMV. Educação para a morte a docentes e discentes de enfermagem: revisão documental da literatura científica. Rev Esc Enferm USP. 2011;45(1):272-6.
21 Lino MM, Backes VMS, Ferraz F, Reibnitz KS, Martini JG. Posturas pedagógicas adotadas no ensino de enfermagem e saúde na região sul do Brasil. Rev Bras Enferm. 2011;64(1):152-9.
Author's address / Endereço do autor / Dirección del autor

Ana Luísa Petersen Cogo

Rua São Manoel, 963, Rio Branco

90620-1 10, Porto Alegre, RS

E-mail: analuisa@enf.ufrgs.br
Received: 29.09.2013

Approved: 03.12.2013 